\title{
Effect of Gayatrimantra chanting on cognitive functions in school children
}

\author{
K. A. Manoj Narayanan ${ }^{1}$, N. Venugopalan ${ }^{2}$ \\ ${ }^{1}$ Dr. K. A. Manoj Narayanan, Assistant Professor, ${ }^{2}$ Dr. N. Venugopalan, Professor, Department of Pediatrics, DM \\ Wayanad Institute of Medical Sciences, Naseera Nagar, Meppadi, Wayanad, Kerala, India.
}

Corresponding Author: Dr. N. Venugopalan, Professor, Department of Pediatrics, DM Wayanad Institute of Medical Sciences, Naseera Nagar, Meppadi, Wayanad, Kerala, India. Email: dr.venugopalan@dmwims.com

\begin{abstract}
Background: In Indian tradition chanting of Vedic mantras is a part and parcel of life. The sacred Gayatri mantra was explained in Rig Veda. It was initially explained by Vishwamitra maharshi. As it is concerned about sun, it is also called as Savir mantra. Methods: Thirty healthy, willing, hostel students (15 boys and 15 girls) in the age group of 11-14 years were included in the study. After recording the baseline values, all the students were trained in Chanting Gayatri mantra for a week days by Veda pundit before the starting of the study. After a week days, the participants started chanting the mantra once a day, for five days a week, early in the morning at 6am under the supervision of Vedic expert for 10 minutes for 16 weeks. Post intervention values were recorded after 16 weeks. Results: Results were presented in tabular form. There was a significant increase in the both spatial and verbal memory scores followed by the chanting of Gayatri mantra. Conclusion: The present study provides further evidence for the beneficial effects of chanting Gayatri mantra. We recommend further detailed studies in this area to understand molecular mechanisms involved.
\end{abstract}

Keywords: Gayatri mantra, Spatial memory, Verbal memory

\section{Introduction}

In Indian tradition chanting of Vedic mantras is a part and parcel of life. The sacred Gayatri mantra was explained in Rig Veda. It was initially explained by Vishwamitra maharshi. As it is concerned about sun, it is also called as Savir mantra [1]. In vedas, it was explained that students should perform the chanting of Gayatri mantra before their formal studies. Gayatri mantra was known to improve the intelligence [2]. Research reported that chanting of mantras has positive impact on both physiological and psychological functions of the body [3]. Earlier study reported that chanting Vedic hymns showed improvement in sustained attention in teenaged school students [4].

Vedic chanting chanting activates the hidden powers of the mind and awake these powers [4]. Chanting enhance their ability to focus attention, the spontaneous organization of memory and short term recall. Chanting increases the blood supply to the areas of the brain which are concerned with the memory. Chanting of Omshowed a significant decrease in skin resistance

Manuscript received: $17^{\text {th }}$ February 2018

Reviewed: $27^{\text {th }}$ Februry 2018

Author Corrected: $6^{\text {th }}$ March 2018

Accepted for Publication: $10^{\text {th }}$ March 2018 level of the experimental group. It also showed reduction in the heart rate and the rate of breathing. There are several studies where interventions like asana, pranayama, meditation etc, studies on vedic chanting and memory are comparatively less. Hence, the present study was undertaken to provide further scientific evidence for beneficial effect of Gayatri mantra chanting on cognitive functions in elementary school children.

\section{Materials and Methods}

Participants- Thirty healthy, willing, hostelstudents (15 boys and 15 girls) in the age group of 11-14 yearswere included in the study from a school in Angamaly, Kerala. The approval was obtained from school authorities and consent was taken from the parents of the participants. The participants acted as self-controls.

Design of the study- After recording the baseline values, all the students were trained in Chanting Gayatri mantra fora week dayby Veda pundit before the starting of the study. After a week days, the participants started 
chanting the mantra once a day, for five days a week, early in the morning at 6 am under the supervision of Vedic expert for 10 minutes for 16 weeks. Post intervention values were recorded after 16 weeks.

Gayatri mantra- Gayatri mantra was chanted with eyes closed. The participants followed the traditional procedure of chanting it loudly for its best effect to invoke the innate power of effulgence and intellect [4].

Outcome measures- Spatial memory test: The power point presentation consisting of 10 slides was prepared and projected using liquid crystal display (LCD) on the screen. Each slide consists of a simple line diagram which is easy to reproduce. Diagrams which could be verbally described like square, circle, rectangle and pyramid were not included for testing. After showing all the 10 slides, a mathematical problem was projected on the screen and asked to solve the problem. Later the participants were asked to recall all the 10 slides projected and draw on a paper within a minute. The correct answer was given a score as 1 and an incorrect answer was scored as 0 . The study used different sets of drawings on different time periods of data collection [5]

Verbal memory test: The power point presentation consisting of 10 slides was prepared and projected using liquid crystal display (LCD) on the screen. Each slide consists of a three letter word like for example ZOL.

After showing all the 10 slides, a mathematical problem was projected on the screen and asked to solve the problem. Later the participants were asked to recall all the 10 slides projected and recollect and present the same on a paper within a minute. The correct answer was given a score as 1 and an incorrect answer was scored as \|\| . The study used different sets of words on different time periods of data collection [5].

Data analysis: Data was analyzed by using SPSS 20.0. Student $t$ testwas used toobserve the significance of difference between the groups.

\section{Results}

Results were presented in table no 1 . There was a significant increase in the both spatial and verbal memory scores followed by the chanting of Gayatri mantra.

Table-1: Spatial and verbal memory scores before and after intervention

\begin{tabular}{|c|c|c|c|}
\hline Parameter & Before intervention $\mathbf{( n = 3 0 )}$ & After intervention $(\mathbf{n}=\mathbf{3 0})$ & P value \\
\hline Spatial memory & $6 \pm 3$ & $8 \pm 1$ & $0.0010^{*}$ \\
\hline Verbal memory & $4 \pm 2$ & $6 \pm 1$ & $0.0001^{*}$ \\
\hline
\end{tabular}

$* \mathrm{P}<0.05$ is significant

\section{Discussion}

Vedas contain such Mantras which directly help enhance the state of individual. The meaning of Gayatri mantra is "the divine and holy light which pervades all that exists, the significant and adorable sun as I meditate on your supreme and sovereign radiance, may you illuminate and brighten my intellect' [6]. It was mentioned in Indian tradition that, Gayatri mantra was the mother of all the Vedas and chanting the mantra will remove all sins. In fact reciting the mantra gives equal effect of reciting the four Vedas.

It was reported that chanting Gayatri mantra regularly shall improve learning power, concentration, prosperity, eternal power, peace and improves quality of life. Studies have reported that brain areas such as orbitofrontal, anterior cingulate, parahippocampal gyri, thalami, and hippocampiactivity significantly decreased both sides followed by chanting mantras [7]. Other studies demonstrated activation of the medial frontal gyrus, which is mainly related to mental concentration and visuospatial attention during chanting of mantras. Further, activation of the left lateral middle frontal gyrus, the right angular gyrus, and the right supramarginal gyrus, which are related to visuospatial attention were activated during chanting [8]. Practicing vedic chanting increase the attention by activating the cells in the brain.

Further it decreases the stress levels and increases the performance of the individual which helps to improve the capability of learning and memory [9]. Decrease in the anxiety and offering calmness of the mind with active cells due to rhythmic Vedic may facilitate memory and sustained attention [10]. Earlier study suggested that chanting improves the memory and attention by influencing both the hemispheres. The study suggested implementation of the Vedic chanting in routine day life style like any other available 
interventions likeasanas, pranayama, meditation etc [11]. Chanting increases the synchronicity of cardiovascularrhythms when they were recited 6 times a minute.

All these studies indicate that recitation of Gayatri mantra may play a role in improving the memory and concentration. In the present study, we have observed significant improvement in the spatial and verbal memory scores followed by the chanting Gayatri mantra.

\section{Conclusion}

The present study provides further evidence for the beneficial effects of chanting Gayatri mantra. We recommend further detailed studies in this area to understand molecular mechanisms involved.

Contribution to existing knowledge: The current study provides further evidence for the improvement in the cognitive functions in students. It provides a base to support inclusion of the chanting in routine day life style.

Funding: Nil, Conflict of interest: None initiated, Perission from IRB: Yes

\section{Contribution of Authors}

Author-1: conception or design of the work, analysis, or interpretation of data for the work, Drafting the manuscript, final approval of the version to be published, agreement to be accountable for all aspects of the work.

Author-2: The acquisition and interpretation of data, revising the manuscript critically final approval of the version to be published, agreement to be accountable for all aspects of the work.

\section{References}

1. Harshananda S. 3rd ed. Chennai: Ramkrishna Math; 2010. Upanayana, Sandhya Vandana and Gayatri Mantra Japa.

2. Bhatta KV. 4th ed. South Canara: Kaitanje Prakashan; 2004. Shri Gayatri Mantra Rahasya.
3. Bernardi L, Sleight P, Bandinelli G, Cencetti S, Fattorini L, Wdowczyc-Szulc J, Lagi A. Effect of rosaryprayer and yoga mantras on autonomic cardiovascularrhythms: comparative study. BMJ. 2001 Dec 22-29; 323(7327):1446-9.

4. Balaram Pradhan and Seema Godse Derle. Comparison of effect of Gayatri Mantra and Poem Chanting on Digit Letter Substitution Task. Anc Sci Life. 2012 Oct-Dec; 32(2): 89-92.

5. Naveen KV, Nagarathna R, Nagendra HR, Telles S. Yoga breathing through a particular nostril increases spatial memory scores without lateralized effects. Psychol Rep.1997 Oct;81(2):555-61.

6. https://www.mostinside.com/miraculous-benefits-ofreciting-gayatri-mantra/.Last accessed on $28^{\text {th }}$ Feb 2018.

7. Kalyani BG, Venkatasubramanian G, Arasappa R, Rao NP, Kalmady SV, Behere RV, Rao H, Vasudev MK, Gangadhar BN. Neurohemodynamiccorrelates of 'OM' chanting: A pilotfunctional magnetic resonance imagingstudy. Int J Yoga. 2011 Jan; 4 (1):3-6. doi: 10. 4103/ 0973-6131.78171.

8. Shimomura T, Fujiki M, Akiyoshi J, Yoshida T, Tabata M, Kabasawa H, Kobayashi H. Functionalbrain mapping during recitation of Buddhistscriptures and repetition of the Namu Amida Butsu: a study in experienced Japanese monks. Turk Neurosurg. 2008 Apr; 18 (2):134-41.

9. Saltz E, Manifest anxiety-have we missed the data, Psychol Rev.1970; 77:568-573.

10. Wallace RK, Benson H, Wilson AF. A wakeful hypometabolic physiologic state. Am J Physiol. 1971 Sep; 221(3):795-9.

11. Sripad Ghaligi, H R Nagendra \& Ramachandra Bhatt. Effect of Vedicchanting on memory and sustained attention. Indian Journal of Traditional Knowledge. 2006;5(2):177-180.

12. Satish Bansilal Patil, K HH V S Narasimha Murthy, Mangalagowri V Rao. Effect of yogic practices and medhyarasayanas on manasa prakriti, adjustment and aggression of adolescent juvenile delinquents. Int. J. Res. Ayurveda Pharm. 2015;6(6):649-655.

\section{How to cite this article?}

K.A.Manoj Narayanan, N. Venugopalan. Effect of Gayatrimantra chanting on cognitive functions in school children.Int J Pediatr Res. 2018;5(3):113-115. doi:10.17511/ijpr.2018.i03.02. 